\title{
Antioxidant, Total Phenolic and Flavonoid Content of Selected Nigerian Medicinal Plants
}

\author{
Matthias Onyebuchi Agbo ${ }^{1}$, Philip Felix Uzor ${ }^{1}$, Uchenna Nneamaka \\ Akazie-Nneji $^{1}$, Chidozie Uzoma Eze-Odurukwe ${ }^{1}$, Uchenna Basilia Ogbatue ${ }^{1}$ \\ and Emmanuel Chukwunwike Mbaoji ${ }^{2}$ \\ ${ }^{1}$ Department of Pharmaceutical and Medicinal Chemistry, University of Nigeria, Nsukka, \\ Enugu State, Nigeria \\ ${ }^{2}$ Department of Pure and Industrial Chemistry, University of Nigeria, Nsukka, Enugu State, Nigeria
}

Received: November 13, 2014; Accepted: February 25, 2015; Published (web): February 26, 2015

\begin{abstract}
Plant phenolics and flavonoids play a great role in scavenging free radicals in the body and act as antioxidants. Thus their determination is sometimes nedded. Total antioxidant capacity, total phenolic and flavonoid contents of the extracts of 10 medicinal plants (Lochnera rosea, Allamanda cathartica, Asplenium platyneuron, Euphorbia prostrate, Baphia nitida, Crotolaria retusa, Zapoteca portoricensis, Platycerium bifurcatum, Mussaenda afzelii and Craterosiphon scandens) from 7 botanical families growing in the tropical rainforest of Nigeria were included in this study. The total antioxidant capacity of the extracts was assessed by using the phosphomolybdate method. The phenolic content was determined by using Folin-Ciocalteau assay, while the total flavonoid was determined by the aluminium chloride colorimetric assay. The results obtained showed that the total antioxidant capacity for all the extracts were in the range of $0.888 \pm 0.75$ to $0.938 \pm 0.00 \mathrm{mg} \mathrm{EAA} / \mathrm{g}$. The results showed that E. prostrate, $P$. bifurcatum and A. platyneuron were found to be the richest source of phenolic $(97.77 \pm 0.77,87.62 \pm 1.22$ and $82.33 \pm$ $0.30 \mathrm{mg} \mathrm{GAE} / \mathrm{g}$ ) while B. nitida and M. afzelii had the least total phenolic content (11.67 \pm 0.09 and11.18 $\pm 0.30 \mathrm{mg}$ $\mathrm{GAE} / \mathrm{g})$. The highest total flavonoid content was revealed in P. bifurcatum (648.67 $\pm 12.3 \mathrm{mg}$ QE) while M. afzelii also had the least total flavonoid content $(3.67 \pm 0.00 \mathrm{mg} \mathrm{QE} / \mathrm{g})$. The ratio of flavonoid to the phenolic in each extract was also determined to ascertain extracts that are rich in flavonoids.
\end{abstract}

Key words: Total antioxidant capacity, total phenolic, total flavonoid, Folin-Ciocalteau, aluminium chloride, gallic acid

\section{INTRODUCTION}

Free radicals are generated in vivo by living cells from the cell metabolism. However, excess free radicals are responsible for some degenerative diseases like atherosclerosis, ischemic heart disease, ageing, diabetes mellitus and cancer. ${ }^{1}$ Free radicals cause oxidative damage to macromolecules in the body, such as lipids, proteins and nucleic acids. Antioxidants prevent such free radicals from oxidative damage to DNA, proteins, and cells by donating electrons to stabilize and neutralize the harmful effects of the free radicals. Plant-derived antioxidants have received greater attention since they act as radical scavengers. Natural antioxidants

Correspondence to: Matthias Onyebuchi Agbo

Tel.: +234 (0) 8162661991

E-mail: matthias.agbo@unn.edu.ng

Dhaka Univ. J. Pharm. Sci. 14(1): 35-41, 2015 (June) are less toxic as compared to their synthetic analogues like butylated hydroxyanisole (BHA) and butylated hydroxyltoluene (BHT), which have been reported to be carcinogenic and cause liver damage. ${ }^{2}$ Plant phenolics are compounds derived from phenylalanine and tyrosine and are among the widely distributed secondary metabolites in the plant kingdom. ${ }^{3}$ Plant phenolics include flavonoids, condensed tannins, coumarins and stilbenes. ${ }^{4}$

Phenolics are regarded as the molecules with the highest potential to neutralize free radicals. These compounds act mainly as antioxidants due to their ability to scavenge free radicals and chelate metals in vitro and in vivo. ${ }^{5}$ Therefore, high consumption of phenolic compounds leads to reduce risk of cardiovascular diseases and cancers. Plant phenolics have been reported to have a lot of biological activities including anti-carcinogenic, antioxidant and anti-mutagenic. ${ }^{6}$ The present study involves 
quantitative determination of total phenolic, total flavonoid content and total antioxidant capacity from ten Nigerian medicinal plant extracts.

\section{MATERIALS AND METHODS}

Chemicals and reagents. Folin-Ciocalteu reagent was obtained from Lobal Chemie (India). Methanol was bought from Sigma-Aldrich (Germany). Sodium hydroxide $(\mathrm{NaOH})$, quercetin, sulphuric acid $\left(\mathrm{H}_{2} \mathrm{SO}_{4}\right)$ and ascorbic acid were purchased from BDH (England). Sodium nitrite $\left(\mathrm{NaNO}_{2}\right)$ and gallic acid were procured from Qualikems (India). Sodium carbonate $\left(\mathrm{Na}_{2} \mathrm{CO}_{3}\right)$, aluminium chloride $\left(\mathrm{AlCl}_{3} \cdot 6 \mathrm{H}_{2} \mathrm{O}\right)$, sodium phosphate $\left(\mathrm{NaH}_{2} \mathrm{PO}_{4}\right)$ and ammonium molybdate were bought from JHD (China). All chemicals used were of analytical grade.

Plant material. The plants Lochnera rosea (Apocynaceae), Allamanda cathartica (Apocynaceae), Asplenium platyneuron (Aspleniaceae), Euphorbiaprostrate (Euphorbiaceae), Baphia nitida (Fabaceae), Crotolaria retusa (Fabaceae), Zapoteca portoricensis (Fabaceae), Platycerium bifurcatum (Polypodiaceae), Mussaenda afzelii (Rubiaceae) and Craterosiphon scandens (Thymelaeaceae) were collected from Orba in Enugu State Nigeria, in the month of March 2014 and authenticated by Mr. Alfred O. Ozioko at the International Centre for Ethnomedicine \& Drug Development (InterCEDD), Nsukka, Nigeria.

Preparation of plant extracts. The air dried plant parts were pulverized and each of the powdered material $(20.0 \mathrm{~g})$ was macerated with $200 \mathrm{~mL}$ of methanol at room temperature for $48 \mathrm{~h}$ with agitation. The filtrates were concentrated in vacuo at reduced pressure and temperature $\left(40^{\circ} \mathrm{C}\right)$ to obtain the extracts. The dried extracts were lyophilized to make them crispy.

Total phenolic content (TPC) determination. Folin-Ciocalteau method was used for the determination of the total phenolic content of the plant extracts using gallic acid as an internal standard with slight modification as previously reported. ${ }^{7}$

Briefly, $1 \mathrm{ml}$ of the extract $(1 \mathrm{mg} / \mathrm{ml})$ was mixed with $9 \mathrm{~mL}$ of distilled water in a $25 \mathrm{~mL}$ volumetric flask. Two and half milliter $(2.5 \mathrm{~mL})$ of a 10 fold dilute Folin-Ciocalteau phenol reagent (FCPR, 1:10) was added. After $5 \mathrm{~min}, 10 \mathrm{~mL}$ of $7.5 \% \mathrm{Na}_{2} \mathrm{CO}_{3}$ solution was added to the mixture and made up to the mark with distilled water. The mixture was incubated in the dark for 90 mins at room temperature. A set of standard solutions of gallic acid (200, 175, 150, 125, and $100 \mu \mathrm{g} / \mathrm{mL}$ ) were prepared in the same manner as described for the extracts. The absorbances of the extracts and standard solutions were read against the reagent blank at $760 \mathrm{~nm}$ with a UV/Visible spectrophotometer (UV-1800, Shimadzu, Japan). The total phenolic content was determined from the calibration curve (Figure1) and expressed as milligram of gallic acid equivalent (GAE) per gram of the extracts. ${ }^{8}$ The determination of the total phenolic in the extract was carried out in triplicate.

Determination of total flavonoid content (TFC). Aluminium-chloride colourimetric assay was used to determine the total flavonoid content in the extracts as previously reported. ${ }^{6}$ Briefly, $1 \mathrm{ml}$ of the extract $(1 \mathrm{mg} / \mathrm{mL})$ was mixed with $4 \mathrm{~mL}$ of distilled water in a $10 \mathrm{~mL}$ volumetric flask. $0.30 \mathrm{~mL}$ of $5 \%$ sodium nitrite was added to the flask. After $5 \mathrm{~min}$, $0.30 \mathrm{ml}$ of $10 \% \mathrm{AlCl}_{3} \cdot 6 \mathrm{H}_{2} \mathrm{O}$ solution was added to the mixture, followed by addition of $2 \mathrm{~mL}$ of $1.0 \mathrm{M}$ $\mathrm{NaOH}$ after another $5 \mathrm{~min}$ and diluted to the mark with distilled water. A set of standard solutions of quercetin $(100,80,60,40$ and $20 \mu \mathrm{g} / \mathrm{ml})$ were prepared in the same manner as described for the extracts. The absorbances of the extracts and standard solutions were measured against the reagent blank at $510 \mathrm{~nm}$ with a UV/Visible spectrophotometer. The total flavonoid content was determined from the calibration curve (Figure 2) and expressed as milligram of quercetin equivalent $(\mathrm{QE})$ per gram of extracts. ${ }^{9}$ The determinations of total flavonoid in the extracts and standards were carried out in triplicates.

Qualitative phytochemical analysis of the extracts. Phytochemical analysis of the plant extracts Antioxidant, Total Phenolic and Flavonoid Content were done to determine the presence of flavonoids, tannins and phenolics according to standard methods. ${ }^{10}$

In vitro antioxidant assay. The in vitro antioxidant assay of the extracts was carried out by 
dissolving $100 \mathrm{mg}$ of the extracts in $100 \mathrm{~mL}$ of distilled water to form stock solutions $(1 \mathrm{mg} / \mathrm{mL}$ or $1000 \mu \mathrm{g} / \mathrm{mL}$ ). Serial dilutions (300, 250, 200, 100, 50 and $25 \mu \mathrm{g} / \mathrm{mL}$ ) of each extract were made from the stock solution. Ascorbic acid (ASA) was used as standard for the assay.

Total antioxidant capacity (TAC). The total antioxidant capacity of the extracts was determined by the phosphomolybdate method. ${ }^{11-13}$ Briefly, 0.1 $\mathrm{ml}$ aliquot of various concentration of the plant extracts (300, 250, 200, 100, 50 and $25 \mu \mathrm{g} / \mathrm{ml}$ ) was mixed with $1 \mathrm{ml}$ of reagent solution $(600 \mathrm{mM}$ sulfuric acid, $28 \mathrm{mM}$ sodium phosphate and $4 \mathrm{mM}$ ammonium molybdate, 1:1:1). The test tubes were covered with aluminium foil and incubated in a water bath at $95^{\circ} \mathrm{C}$ for $90 \mathrm{~min}$. Then the extracts were cooled to room temperature and the absorbance of the mixture was determined at $765 \mathrm{~nm}$ against a blank containing $1 \mathrm{ml}$ of the reagent solution. Ascorbic acid was used as standard. The assay was carried out in triplicate. The total antioxidant capacity (TAC) was expressed as mg equivalents of ascorbic acid per gram (EAA/g). The antioxidant capacity was estimated by using the following formula:

$$
\text { Tatal antioxidant capacity }(\%)=\frac{\text { Absorbance of ascorbic acid - Absorbance of extract }}{\text { Absorbance of ascorbic acid }} x 100
$$

\section{RESULTS AND DISCUSSION}

Extraction yield and phytochemical screening. The percentage yield values of the extracts are shown in Table 1. The percentage yield of the extracts varied from 9.52 to 1.42. M. afzelii had the highest yield while Z. portoricensis stem extract gave the lowest yield. Phytochemical screenings of the extracts showed presence of flavonoids and tannins/phenolics.

Table 1. Percentage yield of different extracts.

\begin{tabular}{lcc}
\hline Plant Extracts & $\begin{array}{c}\text { Part's } \\
\text { investigated }\end{array}$ & \% yield \\
\hline Lochnera rosea & Leaf & 2.8 \\
Allamanda cathartica & Leaf & 6.6 \\
& Stem & 1.8 \\
Asplenium platyneuron & Leaf & 5.38 \\
Euphorbia prostrata & Leaf & 3.65 \\
Baphia nitida & Leaf & 8.26 \\
Crotolaria retusa & Leaf & 4.00 \\
Zapoteca portoricensis & Leaf & 4.0 \\
& Stem & 1.4 \\
Platycerium bifurcatum & Leaf & 4.41 \\
Mussaenda afzelii & Leaf & 9.52 \\
Craterosiphon scandens & Leaf & 4.48 \\
& Stem & 1.93 \\
\hline
\end{tabular}

Percentage yield of the extracts is based on dried plant material.

Total phenolic content. The total phenolic content (TPC) of the different plant extracts measured according the Folin-Ciocalteau method is shown in Table 2. The total phenolic contents measured by the Folin-Ciocalteau method varied between $11.18 \pm 0.30$ and $97.77 \pm 0.77 \mathrm{mg}$ gallic acid equivalent per gram of extract.

Total flavonoid content. The content of total flavonoid of the different plant extracts measured spectrophotometrically by using the aluminium chloride colorimetric assay is shown in Table 2. The flavonoid content of the extracts was expressed as $\mathrm{mg}$ quercetin equivalent per gram of the extract.

Total antioxidant capacity (TAC). The total antioxidant capacity of the extracts was determined by the phosphomolybdate method. The results obtained showed that the total antioxidant capacity for all the extracts were in the range of $0.888 \pm 0.75$ to $0.938 \pm 0.00 \mathrm{mg}$ EAA/g (Table 3, Figure 3).

The percentage yield values of the methanol extracts of the plants are shown in Table 1. Amongst all the extracts, M. afzelii showed the highest yield $(9.52 \%)$, while Z. portoricensis stem extract showed the minimum $(1.42 \%)$. Plants rich in phenolics are being used in the food industry because they retard oxidative degradation of lipids and improve the quality and nutritional value of food. ${ }^{7}$ Total phenolics content of the plant extract is determined either by chemical method or quantitatively by spectrophotometeric method using Folin-Ciocalteau reagent. ${ }^{14}$ This method measures the amount of the extract needed to inhibit the oxidation of the FolinCiocalteau reagent. ${ }^{15}$ Folin-Ciocalteau reagent is sensitive to reducing compounds including 
polyphenols. Phenols react with phosphomolybdic acid in Folin-Ciocalteau reagent in alkaline medium and produce a blue coloured complex (Molybdenum blue). This blue colour complex can be quantified spectrophoto-metrically, thus total phenolic content can be determined. ${ }^{16}$ The total phenolics content (TPC) of the extracts was determined from the regression equation of the calibration curve $(y=$
$0.0046 \mathrm{x}+0.1616 ; R^{2}=0.9561$ ) (Figure 1). $E$. prostrata extract had the highest total phenolics content; whereas the contents obtained from B. nitida was the least. Colorimetric reactions are widely used to determine total flavonoids content in food or medicinal plant samples. Colorimetric assay is easy to perform, rapid and applicable in routine laboratory use and low-cost. ${ }^{4}$

Table 2. Contents of total phenolic and flavonoid in selected medicinal plant extracts.

\begin{tabular}{lllccc}
\hline Plant & Family & $\begin{array}{l}\text { Parts } \\
\text { investigated }\end{array}$ & $\begin{array}{c}\text { Total Phenolics } \\
\text { (mg GAE/g) }\end{array}$ & $\begin{array}{c}\text { Total flavonoids } \\
\text { (mg QE/g) }\end{array}$ & $\begin{array}{c}\text { Flavonoids/Phenolics } \\
\text { (F/P ratio) }\end{array}$ \\
\hline Lochnera rosea & Apocynaceae & Leaf & $56.61 \pm 3.26$ & $95.35 \pm 1.65$ & 1.68 \\
Allamanda cathartica & Apocynaceae & Leaf & $53.35 \pm 1.87$ & $170.30 \pm 0.10$ & 3.19 \\
& & Stem & $38.78 \pm 0.00$ & $140.30 \pm 0.10$ & 3.62 \\
Asplenium platyneuron & Aspleniaceae & Leaf & $82.33 \pm 0.30$ & $135.0 \pm 0.00$ & 1.64 \\
Euphorbia prostrata & Euphorbiaceae & Leaf & $97.77 \pm 0.77$ & $167.0 \pm 0.00$ & 1.71 \\
Baphia nitida & Fabaceae & Leaf & $11.18 \pm 0.30$ & $36.35 \pm 0.17$ & 3.25 \\
Crotolaria retusa & Fabaceae & Leaf & $15.00 \pm 0.00$ & $10.33 \pm 0.00$ & 0.69 \\
Zapoteca portoricensis & Fabaceae & Leaf & $27.66 \pm 1.97$ & $63.67 \pm 0.20$ & 2.30 \\
& & Stem & $23.90 \pm 1.70$ & $25.30 \pm 0.22$ & 1.06 \\
Platycerium bifurcatum & Polypodiaceae & Leaf & $87.62 \pm 1.22$ & $648.67 \pm 12.3$ & 7.40 \\
Mussaenda afzelii & Rubiaceae & Leaf & $11.67 \pm 0.09$ & $03.67 \pm 0.00$ & 0.32 \\
Craterosiphon scandens & Thymelaeaceae & Leaf & $16.43 \pm 1.32$ & $07.00 \pm 0.00$ & 0.43 \\
& & Stem & $19.06 \pm 1.02$ & $05.34 \pm 1.66$ & 0.28 \\
\hline
\end{tabular}

Values are expressed as mean $\pm \mathrm{SD}(\mathrm{n}=3)$. The absorbance against the reagent blank was determined at $710 \mathrm{~nm}$ and $510 \mathrm{~nm}$ with an UVVisible spectrometer for phenolics and flavonoids, respectively. Total phenolics content was expressed as mg gallic acid equivalents (GAE) and total flavonoid content expressed as mg quercetin equivalents (QE)

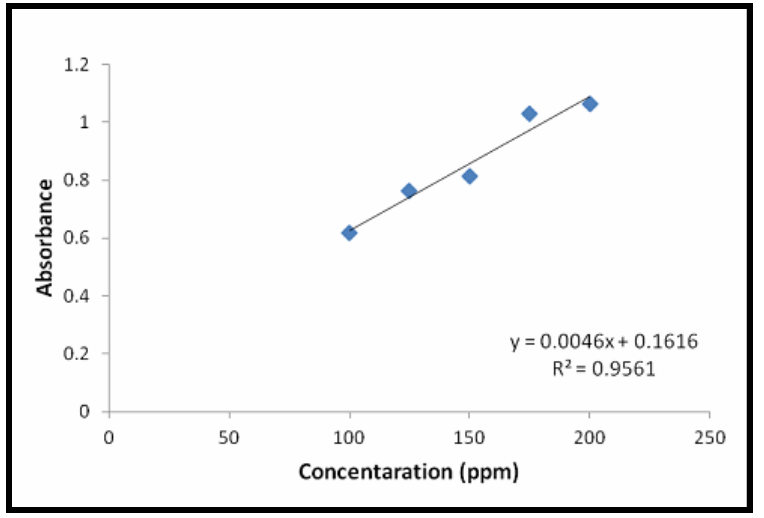

Figure 1. Calibration curve for gallic acid.

Colorimetric method is based on the formation of the flavonoids - aluminium complex which has an absorptivity maximum at $510 \mathrm{~nm}$. The complex formation is carried out in the presence of $\mathrm{NaNO}_{2}$ in alkaline medium ${ }^{17}$ and is based on the nitration of aromatic ring of the flavonoid with free hydroxyl groups at three or four positions. Also, aluminium chloride forms acid stable complexes with the C-4



Figure 2. Calibration curve for quercetin.

keto group and either the C-3 or C-5 hydroxyl group of flavonoids. ${ }^{15}$ The total flavonoids content (TFC) of the extracts was determined from the regression equation for the calibration curve $(y=0.0003 \mathrm{x}+$ 0.0477; $R^{2}=0.9605$ ) (Figure 2). Total antioxidant capacity (TAC) assays involve single electron transfer (SET) and hydrogen atom transfer (HAT). SET assays are easier than HAT assays and involve 
the reduction of an oxidant which results in colour change. ${ }^{18}$ Single electron transfer (SET) assay like the phosphomolybdate method was used in this study to determine the reduction capacity of the extracts. The assay is based on the reduction of $\mathrm{Mo}^{+6}$ to $\mathrm{Mo}^{+5}$ by the extract and subsequent formation of a green phosphate $/ \mathrm{Mo}^{+5}$ complex at acidic $\mathrm{pH}$. Figure 3 shows the percentage total antioxidant capacity of extracts with extracts belonging to the families of Fabaceae, Thymelaeaceae and Apocynaceae having the highest \% TAC. The high phenolics content of the extracts indicates high antioxidant capacity because the phenolics react with active oxygen radicals such as hydroxyl radical, superoxide anion radical and lipid peroxy radical. Studies revealed that there is high correlation between antioxidant capacity
Table 3. Total antioxidant capacity of the extracts.

\begin{tabular}{lll}
\hline Plant Extracts & $\begin{array}{l}\text { Parts } \\
\text { investigated }\end{array}$ & $\begin{array}{l}\text { Phosphomolybdate } \\
\text { assay (mg EAA/g) }\end{array}$ \\
\hline Lochnera rosea & Leaf & $0.918 \pm 0.10$ \\
Allamanda cathartica & Leaf & $0.919 \pm 2.50$ \\
& Stem & $0.917 \pm 0.80$ \\
Asplenium platyneuron & Leaf & $0.906 \pm 0.00$ \\
Euphorbia prostrata & Leaf & $0.888 \pm 0.75$ \\
Baphia nitida & Leaf & $0.935 \pm 0.25$ \\
Crotolaria retusa & Leaf & $0.938 \pm 1.00$ \\
Zapoteca portoricensis & Leaf & $0.897 \pm 1.10$ \\
& Stem & $0.897 \pm 1.10$ \\
Platycerium bifurcatum & Leaf & $0.941 \pm 0.00$ \\
Mussaenda afzelii & Leaf & $0.888 \pm 0.10$ \\
Craterosiphon scandens & Leaf & $0.932 \pm 0.55$ \\
& Stem & $0.938 \pm 0.00$ \\
Ascorbic Acid & - & - \\
\hline
\end{tabular}

Values are expressed as mean $\pm \mathrm{SD}(\mathrm{n}=3)$. The absorbance against the reagent blank was determined at $765 \mathrm{~nm}$ with an UV-Visible spectrometer. Total antioxidant capacity was expressed as $\mathrm{mg}$ equivalents of ascorbic acid per gram.



Figure 3. Percentage total antioxidant capacity (TAC) activity of investigated plant extracts.

$\mathrm{LR}=$ Lochnera rosea, $\mathrm{ACL} / \mathrm{ACS}=$ Allamanda cathartica $($ Leaf $\&$ Stem $), \mathrm{AP}=$ Asplenium platyneuron, $\mathrm{EP}=$ Euphorbia prostrate, $\mathrm{BN}=$ Baphia nitida, $\mathrm{CR}=$ Crotolaria retusa, $\mathrm{ZPL} / \mathrm{ZPS}=$ Zapoteca portoricensis $($ Leaf $\&$ Stem), $\mathrm{PB}=$ Platycerium bifurcatum, $\mathrm{MA}=$ Mussaenda afzelii, SCL/SCS = Craterosiphon scandens (Leaf \& Stem).

and phenolics content. ${ }^{19}$ Our present study showed that $P$. bifurcatum, A. cathartica and B. nitida extracts have high flavonoid/phenolics ratio indicating that the extracts have high flavonoid content. Our data also suggests high correlation between total flavonoids content and antioxidant capacity considering the high antioxidant activity with these extracts. The as methanol extract of $E$. prostrata has been reported to possess scavenging activity in DPPH model. ${ }^{20}$ The antioxidant potential is due to the presence of phenolics and flavonoids which are known to inhibit free radicals. This result agrees with our present study in which the phenolic and flavonoid contents were observed to be high. The 
isolation of polyphenolic compound- quercetin 3-O$\beta$-D-glucopyranoside and a carboxylic acid, chlorogenic acid with antioxidant properties from $P$. bifurcatum has been studied. ${ }^{21}$ The observed antioxidant activity could be attributed to these metabolites. Our present investigation shows that the plant extract had high phenolic and flavonoid contents. In vivo administration of various doses of ethanol extract of $B$. nitida to rats significantly reduced liver anti-oxidant enzymes namely super oxide dismutase (SOD), catalase and peroxidase in a dose dependent manner. ${ }^{22}$ This is an indication that the ethanol extract of $B$. nitida possesses antioxidant activity which could be attributed to the presence of secondary metabolites like flavonoids and phenolics. The present study indicates that the flavonoid to phenolics ratio of the extract is 3.25 indicating that the extract has high flavonoid content, which could be responsible for its antioxidant activity. Study has shown that leaf extract of $Z$. portoricensis significantly increased malondialdehyde (MDA) levels and decrease superoxide dismutase (SOD) and catalase (CAT) activities in experimental rats. ${ }^{23,24}$ This is an indication that the extract has antioxidative potential which is attributed to the presence of flavonoids in the extract, thus supports our present findings. The leaf extract of $C$. roseus (L. rosea) has been shown to reduce the serum cholesterol and total triglycerides levels in normal rats. ${ }^{25}$ This reduction resulted from the presence of flavonoids in the juice, which has antioxidant activity. Our present study agrees with this report, since the extract of L. rosea had flavonoid/phenolics ratio of 1.68 . To the best of our knowledge, no in vitro antioxidant assay of $A$. platyneuron, M. afzelii and C. scandens has been reported.

\section{CONCLUSION}

Extracts of ten Nigerian medicinal plants was investigated for their total antioxidant capacity, phenolics and flavonoids content. Apocynaceae and Fabaceae families were found to be rich in flavonoids, since these families had high flavonoids/phenolics ratio.

\section{ACKNOWLEDGEMENT}

The authors are grateful to Mr. Alfred O. Ozioko of International Centre for Ethnomedicine \& Drug Development (InterCEDD) Nsukka, Nigeria.

\section{REFERENCES}

1. Khatoon, M., Islam, E., Islam, R., Rahman, A.A., Khurshid Alam, A.H.M., Khondkar, P., Rashid, M. and Parvin, S. 2013. Estimation of total phenol and in vitro antioxidant activity of Albizia procera leaves. BMC Res. Notes 6, 121.

2. Zhu, K-X, Lian, C-X, Guo, X-N, Peng, W. and Zhou, H-M. 2011. Antioxidant activities and total phenolic contents of various extracts from defatted wheat germ. Food Chem. 126, 1122-1126.

3. Harborne, J.B. and Williams, C.A. 2000. Advances in flavonoid research since 1992. Phytochemistry 55, 481-504

4. Blainski, A., Lopes, G.C. and de Mello, J.C.P. 2013. Application and analysis of the Folin Ciocalteu method for the determination of the total phenolic content from Limonium brasiliense L. Molecules 18, 6852-6865.

5. Sahu, N. and Saxena, J. 2013. Total Phenolic \& total flavonoid content of Bougainvillea Glabra choisy and Calforina gold flower Extracts. Int. J. Pharm. Tech. 5, 5581-5585.

6. Biju, J., Sulaiman, C.T., Satheesh, G. and Reddy, V.R.K. 2014. Total phenolics and flavonoids in selected medicinal plants from Kerala. Int. J. Pharma. Pharm. Sci. 6, 406-408.

7. Saeed, N., Khan, M.R. and Shabbir, M. 2012. Antioxidant activity, total phenolic and total flavonoid contents of whole plant extracts Torilis leptophylla $\mathrm{L}$. BMC Comp. Altern. Med. 12, 221.

8. Mythili, K., Reddy, C.U., Chamundeeswari, D. and Manna, P.K. 2014. Determination of total phenol, alkaloid, flavonoid and tannin in different extracts of Calanthe triplicate. J. Pharmacog. Phyto. 2, 40-44.

9. Kostić, D.A., Dimitrijević, D.S., Mitić, S.S., Mitić, M.N., Stojanović, G.S. and Živanović, A.V. 2013. Phenolic content and antioxidant activities of fruit extracts of Morus nigra L (Moraceae) from Southeast Serbia. Trop. J. Pharmac. Res. 12, 105-110.

10. Harborne, J.B. 1984. Phytochemical methods: A guide to modern techniques of plant analysis, 2nd edition, Chapman and Hall, New York, p. 288.

11. El-Hashash, M.M., Abdel-Gawad, M.M., El-Sayed, M.M., Sabry, W.A., Abdel-Hameed, E.S. and Lateef, E.E. 2010. Antioxidant properties of methanolic extracts of the leaves of seven Egyptian Cassia species. Acta. Pharm. 60, 361-367. 
12. Jan, S., Khan, M.R., Rashid, U. and Bokhari, J. 2013. Assessment of antioxidant potential, total phenolics and flavonoids of different solvent fractions of monotheca buxifolia fruit. Osong. Public Health Res Perspect. 4, 246-254.

13. Nascimento, A.K.L., Melo-Silveira, R.F., DantasSantos, N., Fernandes, J.M., Zucolotto, S.M., Rocha, H.A.O. and Katia, C.S. 2013. Antioxidant and antiproliferative activities of leaf extracts from Plukenetia volubilis Linneo (Euphorbiaceae). Evidence-Based Comp. Altern. Med. 2013, 950272.

14. Stanković, M.S. 2011. Total phenolic content, flavonoid concentration and antioxidant activity of Marrubium peregrinum L. Extracts, Krag. J. Sci. 33, 63-72.

15. Kale, A., Gaikwad, S., Mundhe, K., Deshpande, N. and Salvekar, J. 2010. Quantification of phenolics and flavonoids by spectrophotometer from Juglans regia. Int. J. Pharma. Bio Scs. 1, 1-4.

16. Pękal, A. and Pyrzynska, K. 2012. Evaluation of aluminium complexation reaction for flavonoid content assay. Food Anal. Methods DOI $10.1007 / \mathrm{s} 12161-014-9814-\mathrm{x}$ in the leaves of Caesalpinia pulcherrima (Linn.). Int. J. Phyto. Res. 2 , 16-19.

18. Phatak, R.S. and Hendre, A.S. 2014. Total antioxidant capacity (TAC) of fresh leaves of Kalanchoe pinnata. J. Pharmacog. Phyt. 2, 32-35.

19. Aliyu, A.B., Ibrahim, M.A., Musa, A.M., Bulus, T. and Oyewale, A.O. 2011. Phenolics content and antioxidant capacity of extracts and fractions of Verninia blumeoides (Asteraceae). Int. J. Biol. Chem. 5, 352-359.
20. Ahmad, M., Shah, A.S., Khan, R.A., Khan, F.U., Khan, N.A., Shah, M.S. and Khan, M.R. 2011. Antioxidant and antibacterial activity of crude methanolic extract of Euphorbia prostrata collected from district Bannu (Pakistan). Afr. J. Pharma. Pharmacol. 5, 1175-1178.

21. Agbo, M.O., Nnadi, C.O., Ukwueze, N.N. and Okoye, F.B.C. 2014. Phenolic constituents from Platycerium bifurcatum and their antioxidatant properties. J. Nat. Prod. 7, 48-57.

22. Akande, I.S., Akande, B.E. and Gbenle, G.O. 2011. Toxicological and antioxidant effects of ethanolic extract of Baphia nitida on diazepam induced oxidative stress in rats. Afri. J. Biochem. Res. 5, 255263.

23. Agbafor, K.N., Ogbanshi, M.E. and Akubugwo, E.I. 2014. Phytochemical screening, hepatoprotective and antioxidant effects of leaf extracts of Zapoteca portoricensis. Adv. Biol. Chem. 4, 35-39.

24. Agbafor, K.N., Akubugwo, E.I., Ukpabi, C.F., Elom, S.O., Ugwuja, E. and Nwachukwu, N. 2014. Wound healing and antioxidant properties of leaf extracts of Zapoteca portoricensis. Int. J. Biol. 3, 2066-2069.

25. Antia, B.S. and Okokon, J.E. 2005. Effect of leaf juice of Catharanthus roseus Linn. on cholesterol, triglyceride and lipoproteins levels in normal rats. Ind. J. Pharmacol. 37, 401-402. 